\section{Salvar para a eternidade: princípios de ciência médica na época de Montaigne e Cervantes}

\section{Save for eternity: principles of medical science in the age of Montaigne and Cervantes}

LOPES, Marcos Antônio. Salvar para a eternidade: princípios de ciência médica na época de Montaigne e Cervantes. História, Ciências, Saúde Manguinhos, Rio de Janeiro, v.16, n.1, jan.-mar. 2009, p.83-94.

\section{Resumo}

$\mathrm{O}$ artigo aborda as artes médicas em uma época em que as terapias se baseavam em conhecimentos empíricos, ditados pela falácia da autoridade de tradições inabaláveis. 'Loucuras' e 'excentricidades' perpetradas pelos artesãos da medicina do Antigo Regime recobram atualidade nos estranhos usos que o novo charlatanismo vem tentando fazer, como por exemplo com as técnicas das células-tronco.

Palavras-chave: saber médico; técnicas terapêuticas; superstição; charlatanismo.

\section{Abstract}

This article approaches the medical arts at a time in which therapies are based on empirical knowledge, dictated by the fallacy of the authority of unshakeable traditions. "Madness" and "eccentricities" perpetuated by Old School medical craftsmen are prevalent today in the strange practices of the new charlatanism, such as trunk cell technologies.

Keywords: medical knowledge; therapeutic techniques; superstition; charlatanism.

\author{
Marcos Antônio Lopes \\ Professor do Departamento de Ciências Sociais \\ Universidade Estadual de Londrina \\ Rua Marília, 233 \\ 86062-560 - Londrina - PR - Brasil \\ malopes@uel.br \\ Recebido para publicação em abril de 2004. \\ Aprovado para publicação em setembro de 2006.
}


A própria escolha de suas drogas tem algo misterioso e sagrado: pé esquerdo de tartaruga, urina de lagarto, excremento de elefante, fígado de fuinha, sangue de asa direita de pombo branco! E para os que como nós sofrem de cólicas nefríticas ..., excremento pulverizado de ratos e outras prescrições absurdas, mais do domínio da feitiçaria do que da ciência.

Montaigne, 1972, p.354

ainda que sei muito bem não haver no mundo feitiços que possam mover e forçar as vontades, como cuidam alguns palermas; o alvedrio das pessoas é livre, e não há erva nem encanto que o obrigue. O que algumas mulherinhas tolas e alguns velhacos embusteiros costumam fazer são certas mistelas e venenos, com que tornam os homens doidos, dando a entender que são específicos para bem-querer, sendo, como digo, coisa impossível forçar-se a vontade de ninguém.

Cervantes, 1981, p.123

$\mathrm{P}$ ertinência e oportunidade de uma obra de pensamento, mesmo muito tempo depois de terem cessado as circunstâncias e motivações que levaram um autor a escrevê-la - eis as máximas virtudes que um livro pode possuir. Aliás, essa é apenas uma das muitas possibilidades de definição de um clássico que continua sempre emitindo seus ruídos através dos séculos. De fato, há livros que, em seu contexto de produção e divulgação, causam fortes rumores, dividem opiniões e, se não chegam a provocar comoções sociais em seu próprio lugar de elaboração, podem ser transformados no credo que vai orientar futuras lideranças revolucionárias. Certos livros de Rousseau são dessa natureza, alguns de Marx e Engels também, após terem passado pelo processo que Julien Benda (1997) denominou 'expressão derivada' da obra intelectual, isto é, aquele processo pelo qual os militantes digerem, reformulam e difundem os textos sob uma roupagem programática.

Por sua própria essência - trata-se de uma longuíssima viagem errática e egóica sobre a natureza humana -, os Ensaios de Montaigne não causaram rumores nem furores em um tempo de controvérsias teológicas e guerras de religião. O fato de Montaigne nunca citar Cristo e demonstrar apenas uma reservada profissão de fé no catolicismo poderia tê-lo tornado objeto de alguma daquelas querelas típicas de seu mundo histórico. Em vida do autor, a obra provocou a admiração dos mais próximos, como o moralista Pierre Charron, além da curiosidade de alguns desconhecidos. Mas na França, nos anos posteriores à morte de Montaigne - ocorrida em 1592 -, não se deu grande atenção ao livro. Contudo ao longo do século XVII, pensadores franceses da envergadura de Descartes e Pascal foram leitores dos Ensaios. Melhor sorte teve a obra na Espanha, Itália e Inglaterra, países nos quais o livro conheceu numerosas edições. Na Inglaterra o livro de Montaigne, além de encontrar amplo público, influenciou escritores do calibre de Bacon e Shakespeare. Sem adentrar os aspectos de sua fortuna crítica, pode-se afirmar que a obra de Montaigne continua atiçando a curiosidade de leitores em pleno século XXI, que nela procuram e encontram uma série de temas, abordando-os em estudos eruditos ou em ensaios mais despretensiosos, como o presente texto. 
Nos séculos XVI e XVII, a precariedade de uma série de recursos - energéticos, alimentares e, sobretudo, médicos -, associada às guerras recorrentes, foi responsável pelos chamados tempos difíceis do Antigo Regime. Vir ao mundo era uma aventura. Permanecer nele ainda mais. Uma simples gravidez era ameaça séria de óbito da mãe ou da criança. A família constituía a primeira e incontornável referência de culturas camponesas, fortemente marcadas por um regime de escassez de alimentos, medos intensos derivados de crendices e superstições, além de toda espécie de violência, escreve o historiador francês Robert Muchembled (1993). Naquela época, que apresentou elevadas taxas de mortalidade infantil, a indiferença social diante da infância não significava exatamente ausência de sensibilidade, mas sim uma espécie de 'estratagema coletivo', desenvolvido inconscientemente para suportar a morte freqüente de recém-nascidos (Muchembled, 1993). O escritor francês Michel de Montaigne também retratou essa realidade. Nos Ensaios, obra complexa em que disserta sobre praticamente todos os assuntos imagináveis ${ }^{1}$ - e também acerca dos temas mais inconcebíveis -, ele relata com naturalidade os vários filhos que perdeu, ainda bastante jovens. Dos seis que nasceram de seu casamento, apenas a segunda filha chegou à idade adulta. Alguns autores formularam a tese da sífilis de Montaigne, mas os montaignistas não são unânimes acerca dessa explicação (Lacouture, 1998). Nos séculos do Antigo Regime eram necessários ao menos dois filhos para ser adulto. Reflexos mentais e conformismos coletivos permitiam suportar o máximo possível essa tragédia incontestável constituída pela 'hecatombe dos inocentes', ressalta Muchembled.

A morte era uma companheira íntima nas sociedades do Antigo Regime. Se homens como Luís XIV e Voltaire tiveram vida longa, isso foi certamente exceção até nos meios sociais mais abastados. Para ilustrar a precariedade da saúde dos homens do Antigo Regime basta citar a perplexidade de Voltaire que, achando estar sempre às portas da morte, não entendia por que vivia tanto: morreu aos 84 anos! Na faixa dos quarenta anos, sofrendo dolorosamente da maladie de la pierre ('pedra nos rins'), Montaigne se descreve como um velho, alguém muito perto de baixar à sepultura. Viveu até quase os sessenta anos uma existência cheia de achaques, sempre se queixando das dores intensas provocadas pelas cólicas renais. A expectativa de vida média muito baixa levou a se considerar, à época - em uma sociedade ordenada por uma concepção transcendente do mundo -, que o ciclo do destino humano sobre a Terra seria comparável ao da existência de Cristo, ou seja, teria duração aproximada de 33 anos. Ao contrário do que ocorre em nosso tempo, os homens aprendiam a sofrer e a morrer com resignação. A morte, sempre à espreita, só era temida quando de natureza violenta, ceifando a vida sem preparação prévia da agonia, que enseja ao cristão repensar os desvios da vida para alcançar a paz de consciência. Como ressalta Muchembled (1993), em casos de morte em duelo a estratégia do moribundo era compensar a falta da extrema-unção pelo perdão incondicional do agressor.

Durante o Antigo Regime as calamidades que levavam à fome e, por extensão, às epidemias eram encaradas como fenômenos naturais, inscritos no plano divino da organização do mundo. Para muitos teólogos e filósofos valia a seguinte equação: doença igual a pecado, que é igual à morte. Desconhecendo princípios elementares de higiene, a sabedoria camponesa concebia a doença como uma agressão oriunda do mundo exterior, sem qualquer relação com o lixo freqüentemente depositado a poucos metros da porta de casa, onde também eram lançados os dejetos de seus moradores, escreveu Lucien Febvre (1950). 
Naquele tempo também a alimentação pobre em nutrientes propiciou pestes e epidemias recorrentes. Doenças endêmicas como lepra, malária, difteria e, depois, sífilis causaram ondas de medo coletivo. Para Fernand Braudel (1989), o Antigo Regime era um mundo de penúrias, escassez e fome:

Hoje, elas atuam; ontem, eram os flagelos do apocalipse: a peste, em epidemias regulares, que só deixarão a Europa no século XVIII; ... a tifóide e a varíola, que são endêmicas; a tuberculose, presente desde cedo nos campos e que, no século XIX, submerge as cidades e converte-se no mal romântico por excelência; enfim, as doenças venéreas, a sífilis que renasce ou, melhor dizendo, explode por combinações de espécies microbianas, após a descoberta da América. As deficiências da higiene, a má qualidade da água potável, fazem o resto (p.16).

O convívio com animais dentro de casa era fonte insuspeitada de uma série de moléstias. A presença de vacas no ambiente doméstico - "animal precioso", segundo Lucien Febvre (1950), porque muitas vezes constituía-se no único bem familiar -, dormindo sob o teto da família camponesa, separadas apenas por um tabique, era comum. Como afirma Emmanuel Le Roy Ladurie (1994), nessas populações rurais na França de fins da Idade Média e inícios da Época Moderna, "a exploração agrícola é centrada na casa, da qual uma parte, separada por um tapume, é reservada à estabulação dos animais: carneiros, bois, porcos, mulas, no inverno, vêm amontoar-se ali, entre quatro paredes, na proximidade dos quartos e da cozinha de seus donos" (p.25).

Acerca da precariedade das condições sanitárias naqueles tempos, Fernand Braudel (1989, p.16) indagou: "Como o homem, após seu frágil nascimento, escaparia a todas essas agressões? A mortalidade infantil é enorme, como em certos países subdesenvolvidos de hoje; o estado sanitário geral, precário. Possuímos centenas de relatos de autópsias desde o século XVI. São alucinantes. A descrição das deformações, das deteriorações dos corpos e da pele, a população anormal de parasitas alojados nos pulmões e nas vísceras deixariam estupefato um médico de hoje".

Em A vida quotidiana em Inglaterra no tempo de Isabel I, Léon Lemonnier (s.d., p.20) observa que "os maus cheiros eram tão intensos que se deitava perfume por todo o lado. Quando uma sala estava demasiado suja para nela se poder viver, neutralizava-se o mau cheiro queimando bagas de zimbro ou ervas aromáticas. A bicharia proliferava naturalmente e, mesmo durante as visitas reais, as pessoas, ao partir, iam mordidas dos pés à cabeça. Uma dama do tempo de Isabel conta que, por ter estado sentada numa sala, ficou coberta de piolhos".

Acerca de infestações de piolhos e outras 'coisas vivas' que transitavam tão natural e livremente pelos corpos das pessoas, Cervantes oferece um depoimento bastante curioso no conhecido episódio da Barca Encantada, capítulo 29 da segunda parte de Dom Quixote, quando o Cavaleiro da Triste Figura passa a crer que havia chegado a partes remotas do Mar Oceano, o Atlântico. Descontando-se os aspectos ficcionais, é de acreditar que o autor tenha composto a cena com elementos cotidianos dos homens de seu tempo, incluindo aquelas pequenas misérias que integravam todos, aristocratas e camponeses, numa escala miúda de humanidade. Pelo humor incomparável de Cervantes (1981), vale a citação de um trecho da passagem: 


\begin{abstract}
- Saberás, Sancho, que os espanhóis e os que embarcam em Cádis para ir às Índias Orientais, um dos sinais que têm para saber se passaram a linha equinocial que eu te disse é que a todos que vão no navio morrem os piolhos, sem que fique um só, que não se encontrará em todo o baixel, nem que se pese a ouro, e assim podes, Sancho, verificar o caso. Se encontrares coisa viva, sairemos com certeza desta dúvida. ... Apalpou-se Sancho e, pondo a mão na barriga da perna esquerda, levantou a cabeça, olhou para seu amo e disse: - Ou a experiência é falsa, ou ainda não chegamos aonde Vossa Mercê diz, nem estamos a poucas léguas de tal sítio. - Pois quê!, perguntou Dom Quixote, encontraste algum? - Alguns, diga Vossa Mercê, respondeu Sancho. E, sacudindo os dedos, lavou a mão toda no rio... (p.430).
\end{abstract}

Na época dos reis absolutistas predominou um sistema de crenças pleno de misticismo e superstições. As práticas médicas, por exemplo, chamam a atenção do observador de nosso tempo como procedimentos muito rudes. O que se poderia caracterizar, hoje, como as excentricidades experimentais de curandeiros eram, verdadeiramente, expressões da lógica peculiar da mais douta ciência. No filme As loucuras do rei George - aqui citado como uma apropriada tentativa de reconstituição dos costumes de época e não certamente como testemunho de verdade histórica -, hilárias são as cenas do tratamento dispensado ao rei da Inglaterra George III, nos finais do século XVIII. Provavelmente esse monarca sofria de porfiria, doença que ocasiona perturbação mental com sintomas de histeria e paranóia (Farquhar, 2003, p.229). Um de seus médicos, que representa a máxima sofisticação dos sistemas terapêuticos da época, simplesmente não compreende como o rei persistia em sua loucura, se suas fezes e urina apresentavam consistência, cheiro e coloração normais. Para um graduado membro do Colégio Real dos Médicos, na Inglaterra do século XVIII, havia uma estreita correlação entre excreções humanas e sanidade mental. Com efeito, os desatinos dos especialistas em cura daqueles tempos são um dos aspectos mais curiosos do filme e sugerem como se podia agravar, ainda que involuntariamente, os males de quem se tencionava salvar a vida.

Isso para afirmar que pacientes eram envenenados ou debilitados pela própria terapêutica que se lhes aplicava. Os regimes alimentares receitados pelos médicos também foram objeto de atenta reflexão. Cervantes, por exemplo, que era filho de um barbeiro sangrador itinerante - espécie de cirurgião daqueles tempos - ria das dietas que esses profissionais prescreviam a seus pacientes. Com o devido desconto à ficção, cenas hilárias a esse respeito encontram-se na segunda parte de Dom Quixote, em que são narradas as peripécias de Sancho Pança - então governador da ilha Baratária - com o seu médico particular, que simula querer matar por inanição o rotundo escudeiro ao impor-lhe dieta de chás e biscoitinhos. Que penitência dos diabos era aquela? - indaga um colérico Sancho Pança, já àquela altura altíssimo personagem, instalado que estava nas culminâncias do poder. É que tudo era feito para poupar as suas ilustres tripas de inflamações e outras moléstias, responde-lhe seu médico. Pilhérias cervantinas à parte, Sancho é antípoda de Dom Quixote: é o contraste da carne com o espírito, do estômago com o cérebro, da realidade com o sonho. Enfim, Sancho é "a voz da barriga protestando contra a alma" (Orwell, citado em Watt, 1997, p.85). Das espertezas entremeadas à ingenuidade do fiel escudeiro provém a hilaridade das cenas por ele protagonizadas quando ocupava o honroso título de governador de sua famosa ilha imaginária. 
Sem dúvida, a natureza agressiva de boa parte das terapias dispensadas aos doentes chocava as pessoas mais avisadas do tempo. No século XVI Montaigne (1972) já fazia pilhéria dos tratamentos médicos predominantes em sua época: "De costume a cura só se obtém em detrimento da vida; fazem-nos incisões, cauterizam-nos, privam-nos de alimento, tiram-nos sangue; um passo a mais e ei-nos curados para sempre" (p.171). A esse respeito vale lembrar o caso do bufão Jean-Antoine Lombard, narrado pelo historiador Georges Minois (2003). Hábil e audacioso, Lombard tornou-se cirurgião da armada francesa nos finais do reinado de Francisco I, após uma breve e precária temporada de estudos de medicina. Como cirurgião da armada, "inventa uma poção mais mortífera que os mosquetes inimigos", escreve Minois. Condenado à morte, safou-se pelo charme de sua irreverência. Declarou ao delfim, o futuro Henrique II, que salvando a todos os seus pacientes para a eternidade, nunca dera motivos para que fossem importunar as autoridades com reclamações. Foi alçado à condição de bobo da corte, ofício prestigioso e de boa remuneração (p.285ss).

Para Montaigne a medicina era uma infinidade confusa de opiniões, um universo vasto e turvo de erros, enfim, uma montoeira perigosa de crendices. Algumas técnicas terapêuticas eram realmente bastante eficazes, notava o filósofo - para apressar a morte, bem entendido: "Quando nos faltam males verdadeiros, a ciência no-los fornece. ... O que digo dos efeitos nefastos da medicina aplica-se igualmente a qualquer outra ciência" (Montaigne, 1972, p.231). Acerca de um circunstanciado relato das concepções médicas predominantes no século XVI, além de divertidas referências às superstições diversas da medicina em todos os tempos, vale ler o texto que o autor escreveu a Madame Duras, "Da semelhança dos filhos com os pais", capítulo final da segunda parte dos Ensaios. Aí Montaigne se diverte, ao mesmo tempo em que faz a alegria do leitor com uma infinidade de gozações, como a do mau lutador grego que, malogrado em seu ofício, tornara-se médico. Um filósofo zombeteiro, Diógenes, ao saber da nova profissão do frustrado pugilista, disse ao novo discípulo de Esculápio: "coragem, vais agora derrubar todos os que te derrubaram outrora" (p.353).

Para o bem ou para o mal, no século de Montaigne havia uma considerável escassez de médicos certificados. Considera-se que em Paris, por volta de 1550, não se contavam além de setenta médicos, para uma população estimada em trezentos mil habitantes. Em $A$ vida quotidiana no tempo do Renascimento, o historiador Abel Lefranc (1938) relata as atividades de um profissional renomado que, perseguido por uma multidão diária de pacientes, "muitas vezes era obrigado a jantar em pé, dando as suas indicações ou examinando as urinas, enquanto mastigava" (p.165). Uma fonte literária portuguesa dos meados do século XVIII, a célebre Arte de furtar - obra anônima, apesar da autoria conferida retrospectivamente ao padre Vieira - demonstra que a celebridade no ramo das curas podia ser conquistada por experiências meramente empíricas. É o que se deduz do diálogo entre um cardeal e um conhecido ferrador de mulas, pilhado em seu novo ofício. A hilaridade da cena, apesar do barroquismo da prosa, vale a extensa citação:

Um ferrador, vizinho do cardeal Palloto, desapareceu de Roma; e indo depois o cardeal a Nápoles, com certa diligência do sumo pontífice, teve um achaque, sobre que se fez junta de médicos, e entre eles veio o ferrador por mais afamado. Conheceu-o o cardeal, tomou-o à parte e perguntou-lhe quem o fizera médico. Respondeu que só mudara de fortuna e não de 
ofício, porque, do mesmo modo que curava, em Roma, as bestas, curava, em Nápoles, os homens; e que lhe sucedia tudo melhor, porque além de acertar nas curas tão bem e melhor que os demais médicos, se acertava, por erro, de dar com algum doente na outra vida, que ninguém o demandava por isso com sua eminência, que lhe fez pagar uma mula do seu coche, por lhe morrer nas mãos andando em cura. O que mais sucedeu no caso não serve ao intento; mas do dito se colhe que anda o mundo errado na matéria de médicos e boticários, que há mister grandíssima reforma, porque, tendo por ofício assegurar as vidas, não só no-las tiram, mas sobre isso nos pedem as bolsas. ... E estes senhores ficam-se rindo e aguçando a ferramenta, para irem por diante da matança de que fazem um ofício. (Anônimo, 2005, p.36).

Das 'esquisitices' do saber médico da Época Moderna nos fala longamente o historiador Sérgio Buarque de Holanda (1994) em Visão do paraíso. Ao descrever a antiga sabedoria de espanhóis e portugueses que estiveram nas Índias Ocidentais e tomaram contato com a sua exuberante e misteriosa natureza - por meio de testemunhos compilados em vasta literatura do século XVII —, Sérgio Buarque estuda a crença no poder curativo de certas plantas e animais. Aqui, chama-se a atenção para determinadas virtudes terapêuticas do gambá. Com base no depoimento do padre Simão de Vasconcelos, autor da Crônica da Companhia de Jesus do Estado do Brasil, de 1663, ele transcreve da obra do jesuíta: "o gambá fornecia a muitos colonos mezinha admirável para todo achaque, pois sua cauda, pisada e misturada com água na quantidade de uma onça, era excelente contra doenças de rins, especialmente as litíases, tomada em jejum, além de curar cólicas, fazer gerar o leite, tirar espinhas, se mastigada, acelerar o parto ..." (citado em Holanda, 1994, p.223ss.).

As receitas baseadas em conhecimentos fundados ao longo de gerações não economizavam nas variações mais curiosas. O pepino, por exemplo, figurava nessa farmacologia estritamente empírica como eficaz repelente de insetos. É o que afirma o tratado alemão de sabedoria médica popular intitulado Os admiráveis segredos de Alberto, o Grande, publicado em 1703, em finais da Idade Média. Para erradicar percevejos, o livro recomenda apanhar um pepino em forma de serpente, mergulhá-lo em água para, em seguida, esfregá-lo na cama infestada. Excremento de boi era recomendado para o mesmo fim, com a garantia expressa de que nenhum percevejo jamais seria encontrado nessa cama. Já o excremento de rato misturado com mel era recurso infalível para a calvície; a sua fricção tópica promovia a recomposição dos pêlos, em qualquer parte do corpo em que tinham existido (cf. Sallmann, 2002, p.172-173). Na Inglaterra dos tempos de Elizabeth I, essa medicina popular deixou registros bem curiosos. "O excremento de pombo, colocado sobre uma ferida, produz imediata cura", descreve o historiador francês Léon Lemonnier (s.d., p.312).

Ainda no reino dos excrementos, o de cachorro era indicado para disenteria. Mas, para surtir o efeito desejado, seria necessário trancar o cão por três dias, alimentando-o nesse período apenas com ossos. A cólica poderia ser combatida facilmente com excremento de lobo diluído em vinho. Contra a escrofulose, excremento de boi. Males da garganta eram perfeitamente curáveis com o emprego do excremento humano, bastando apenas um pouco de cuidado com a dieta de quem iria fornecê-lo - de preferência um jovem de bom temperamento. Recomendava-se rejeitar o material produzido no primeiro dia e coletar apenas o dos dois dias seguintes, adicionando a mesma quantidade de mel. Não havia amigdalite que resistisse a essa mistura. É o que está expresso no manual de curas Os admiráveis segredos. A ingestão de urina humana era receitada para moléstias variadas; apesar da 
repugnância natural provocada, não havia nada mais eficiente contra as tinhas (dermatoses provocadas por fungos), as úlceras dos ouvidos e as chagas de um modo geral. Para a epilepsia, pó de osso humano moído em solução aquosa. Outras substâncias moídas, como as aranhas, curavam a febre terçã. Já o cérebro do gato era remédio certeiro para as inflamações provocadas por febres violentas, bastando friccioná-lo no pescoço. ${ }^{2}$

À época, em que predominavam influências mágicas numa medicina essencialmente empírica, excrementos eram considerados elementos essenciais tanto para a terra como para o corpo humano, ambos dimensões indissociáveis do ciclo da vida. A historiadora do saber médico no Brasil colonial Márcia Moisés Ribeiro (1997) explica uma entre as várias sutilezas implicadas nessas terapias: "Se o excreto dá vida à terra cansada, pode também proporcionar a saúde ao homem doente; portanto, ele é vitalizador" (p.71), afirma. E prossegue: "A doença era, muitas vezes, percebida como a prova da ira de Deus; assim sendo somente com penitências - como a ingestão de substâncias repugnantes - é que se alcançaria um bom estado de saúde" (p.72). Já segundo Jean-Michel Sallmann (2002, p.172), "sempre existiram receitas e fórmulas destinadas a prevenir, curar, em um domínio em que somente o empirismo tinha crédito. Em uma época em que as tradições se transmitiam oralmente, os eruditos recolheram esse conhecimento popular e codificaram suas fórmulas eternas".

Acerca do advento de uma nova arte médica a partir da primeira metade do século XVI, os historiadores Ruggiero Romano e Alberto Tenenti (1972) analisam as transformações ocorridas na Itália a partir dos trabalhos de Vesalio e Fracastori. Romano e Tenenti ressaltam as novas exigências do ensino na Itália do Renascimento, que passaram a vincular a prática cirúrgica - até então domínio de barbeiros sem qualquer conhecimento teórico -, com a especulação abstrata dos professores. As críticas de Vesalio às formas tradicionais do saber acabaram gerando resultados. Aos poucos, o tradicional barbeiro foi desaparecendo de cena nas telas de lições de anatomia, nas quais representava antes o papel de protagonista da experiência cirúrgica. O professor, que possui o domínio do saber teórico, passou à condição de executor da demonstração empírica (p.157).

No século XVII Cervantes zombava das poções destinadas a regenerar milagrosamente as feridas e demais contusões. Em Dom Quixote, o bálsamo feito pelo Cavaleiro da Triste Figura revelou-se um vomitório tão poderoso que quase arranca as tripas do combalido Sancho Pança. A literatura romântica do século XIX, que valorizou as tradições populares antigas, também não deixou de rir das esquisitices dos profissionais da saúde do Antigo Regime. Em Os três mosqueteiros, Alexandre Dumas (1982, p.21) descreveu a cura surpreendente de seu protagonista, por manter-se a prudente distância daqueles 'profissionais': "Aplicando as compressas ele mesmo, não permitiu que nenhum médico interviesse. Dessa forma, graças ao bálsamo, e provavelmente à ausência dos médicos, d'Artangnan conseguiu ficar em pé naquela mesma noite e sentiu-se quase recuperado no dia seguinte". D'Artangnan usara um ungüento preparado a partir de uma fórmula que lhe entregara sua mãe provavelmente uma curandeira - quando partiu da Gasconha para Paris. Naturalmente trata-se, nesses dois casos, de personagens literários e, portanto, ficcionais; aqui importa apenas o registro de como autores de diferentes tempos lidaram com essas referências culturais populares. 
Durante o Antigo Regime, as práticas predominantes nos tratamentos baseava-se na teoria dos humores. Partia-se do princípio de que o corpo humano se constituía de quatro fluídos, os ditos humores: o sangue, a fleugma, a bile amarela e a melancolia. O excesso de um deles era a causa dos desarranjos físicos. A loucura de Dom Quixote, por exemplo, não era vista por Cervantes como nós a enxergamos hoje, ou seja, como um desequilíbrio mental ou desarranjo dos nervos. Cervantes construiu um personagem de temperamento bilioso, tendente a achaques de ira em circunstâncias específicas. Exemplo disso são suas explosões de cólera quando diante de inimigos reais ou imaginários. Jean Delumeau (1996) oferece pistas para a compreensão da personalidade de Dom Quixote, conforme os atributos conferidos ao personagem por Cervantes: "em um tempo em que a instabilidade psíquica era grande, os indivíduos em sua vida social passavam constantemente de um extremo ao outro e da violência ao arrependimento" (p.405). Sem dúvida, a dita 'instabilidade psíquica' pode ser compreendida como um domínio ainda frágil de certas normas de civilidade o que, certamente, dava azo a comportamentos coléricos. Com efeito, Ian Watt (1997, p.80) afirma: "É difícil imaginar ... que Dom Quixote se tornasse personagem universalmente popular se de fato fosse um louco no sentido moderno". Em vista disso, toda cura se deveria dar pelo método de purgar o humor em excesso por meio de sangrias ou medicamentos variados, como atesta um expressivo testemunho de época: "Estamos sujeitos a superabundâncias de humores inúmeros e nocivos; temem-nos os médicos, mesmo quando esses humores fazem parte dos que se consideram benéficos ... . É por isso que prescrevem purgantes e sangrias aos atletas" (Montaigne, 1972, p.316s).

Em complexo livro sobre o pensamento de Montaigne, Jean Starobinski (1992) explica a teoria geral dos humores, aceita pela ciência médica nos tempos em que dominava o empirismo popular - ou seja, a sabedoria baseada em aparências (e no que disse Aristóteles, claro!). Por seu conteúdo esclarecedor, vale a citação literal: "Para a fisiologia da Renascença, a melancolia (ou atrabílis) é, com o sangue, a bílis e a fleuma, um dos quatro humores fundamentais cuja mescla determina o 'temperamento' do indivíduo. A feliz proporção dos humores faz do corpo um instrumento que a alma governa sem muita dificuldade. Mas todo desequilíbrio, e sobretudo o excesso da bílis (ou cólera) ou da melancolia, permite à paixão corporal assumir o comando" (p.31).

Tais limitações, ou melhor, singularidades ou especificidades do conhecimento médico levaram a fenômenos culturais surpreendentes durante o Antigo Regime, como os processos de caça às bruxas. Jean-Michel Sallmann (2002, p.41) argumenta: "Não há dúvidas de que a crença em feitiços se desenvolveu em grande parte devido às insuficiências da medicina. A doença e seus mistérios se ofereceram naturalmente. Será preciso esperar o fim do século XVII para que se registrem progressos, essencialmente no domínio da higiene e da profilaxia. E será no meio médico parisiense que se levantarão, no começo do século XVII, as primeiras vozes que contestarão a existência do crime de bruxaria".

Quanto às condições materiais de existência à época do Antigo Regime, havia uma estreita dependência dos homens em relação ao ritmo da natureza, sobretudo pela escassez de fontes de energia. Assim, atividades produtivas no campo e em oficinas restringiam-se à luz do dia. Além do mais, as moradias eram muito precárias, tanto nas áreas urbanas quanto no espaço rural. A casa limitava-se a poucos cômodos, comuns às pessoas e ao seu 
rebanho. Até o início do século XVIII, nada havia de estranho no fato de várias pessoas dormirem na mesma cama, como demonstram, por exemplo, os estudos de Philippe Ariès e Robert Muchembled. Conforto e intimidade eram valores quase ignorados até mesmo entre aristocratas e burgueses ricos. Os sanitários privados ainda não existiam, e as necessidades corporais eram feitas em qualquer lugar, inclusive diante de estranhos. Também inexistiam ainda as 'boas maneiras'. A faca foi o único 'talher' conhecido no Ocidente cristão até meados do século XVI. Na França a introdução do prato, do garfo e de colheres individuais deu-se apenas no reinado de Henrique II, por volta de 1547. Norbert Elias (1990) conta a curiosa história de uma princesa de Istambul que, na Itália do século XVI, causou estupor na aristocracia veneziana ao comer com um garfo de três pontas. Sobre a Inglaterra, Léon Lemonnier (s.d., p.25) afirma: "Antes de 1563, à mesa, fazia-se circular água e toalhas para lavar as mãos, depois de ter comido com os dedos. Não havia grande preocupação com as boas maneiras à mesa. Antes de 1611, os garfos não eram utilizados. Palitar os dentes em público era então um sinal de fidalguia".

Com o tempo, em diferentes regiões da Europa, as regras de civilidade ultrapassaram as simples atitudes à mesa e se tornaram elementos-chave daquilo que se começou a denominar a arte da conversação. Nos Ensaios, refletindo acerca da força de certos hábitos na conduta dos homens, Montaigne (1972) narra uma passagem curiosa sobre as boas maneiras que começavam a se tornar objeto de reflexão intelectual no século XVI:

Certo fidalgo francês, famoso pelo seu espírito, assoava com os dedos o nariz, coisa contrária aos nossos usos. Defendendo sua maneira de se conduzir, perguntou-me por que motivo tão sujo excremento merecia que tomássemos de um lenço delicado para recebê-lo. E o que é pior, para com isso fazer um embrulho e guardá-lo preciosamente. Era por certo mais repugnante esse hábito do que se desembaraçar de qualquer maneira como procedemos com as demais sujidades. Achei que sua observação não pecava inteiramente por absurda. O hábito impedirame até então de perceber o estranho da coisa, a qual nos repugnaria profundamente se no-la apresentassem como sendo praticada em outro país.

Antes de concluir, apenas mais algumas observações. Já se falou aqui da riqueza temática dos Ensaios. Sobre esse aspecto, Jean Starobinski (1992) qualifica o livro de Montaigne como "o manual do fidalgo perfeito" (p.26), no qual o autor quer glorificar - sem nenhum paralelo na literatura de sua época - as mais prosaicas dimensões da vida. Para tanto, Montaigne desenvolve um vastíssimo elenco de temas, em que a crítica à ciência médica, sem dúvida, ocupa um espaço destacado. Nas palavras de Starobinski, ele "se atribui o direito de olhar para tudo o que se oferece ao seu alcance: para a consciência e a existência pessoais fundamentalmente, mas também para a sabedoria e a insensatez do mundo, para as ações e as sentenças memoráveis, as leis, os costumes, os abusos do universo inteiro" (p.109).

A ousadia e originalidade do projeto intelectual de Montaigne estão na naturalidade com que explora temas estranhos, desaconselhados ou até interditos pela cultura oficial, como as funções corporais e o sexo. A título de exemplo, destaco duas passagens das mais singulares e divertidas dos Ensaios. Primeiro, a da mulher que se viu tomada, em meio à invasão do exército inimigo, por um batalhão de soldados. À lembrança da 'abordagem' inesperada que sofrera, ela murmurava, para alívio de sua consciência religiosa: "Graças a 
Deus, ao menos uma vez na vida pude saciar-me sem estar em pecado" (Montaigne, 1972, p.173). Outra passagem curiosa é a referência aos atos de superexcitação sexual. Montaigne cita o caso do embalsamador egípcio: em vez de fazer o seu trabalho, conspurcou o cadáver da morta, "o que deu origem a uma lei determinando que os corpos das mulheres jovens e belas ou de boa família só fossem entregues ao artesão três dias depois do falecimento" (1972p.406).

Em síntese, a arte de curar sempre foi tema livre para as mais diferentes maquinações. Como tentei demonstrar, fontes literárias, da Antiguidade ao século XIX, são ricas em relatos que, vistos à luz dos avanços do último século, enchem enciclopédias de 'esquisitices'. Assim como toda obra de alcance universal, o livro Ensaios, de Michel de Montaigne, é fonte rica em depoimentos e análises que ilustram a cultura médica de seu tempo, bem como, por contraste, a nossa própria realidade.

Com efeito, em tempos de transplantes de rosto e de outras façanhas louváveis da medicina contemporânea, as experiências com células-tronco acrescentam algumas curiosidades à história das artes médicas. Episódios recentes divulgados pela imprensa escrita e televisiva, como alguns tratamentos com 'células em pó', permitem pensar na pertinência das reflexões de Montaigne, que nos ensinam a rir das superstições, dos charlatanismos e das velhacarias.

\section{NOTAS}

${ }^{1}$ Muito se comenta sobre essa vastidão temática de Ensaios. Montaigne viajou muito e a suas cavalgadas acrescentou, ao longo de vinte anos, a variedade de suas curiosidades intelectuais: "ele está tão atento ao que diz respeito aos usos regionais quanto às técnicas propriamente terapêuticas. Alhures, considera com um interesse igual tudo o que encontra de novo ou de insólito; o comportamento nas ruas ou nos albergues bem como as cerimônias principescas, as máquinas dos artesãos bem como os monumentos e jardins, as especialidades culinárias bem como os traços e documentos da história" (Tournon, 2003, p.67).

${ }^{2}$ Mais detalhes desse receituário encontram-se na seção Testemunhos e Documentos, segundo a tradução francesa da obra do teólogo e filósofo alemão Albert le Grand (citado em Sallmann, 2002, p.172s).

${ }^{3}$ Bastante instrutivo quanto ao tema das moléstias do ponto de vista das tendências emergentes da pesquisa historiográfica nos anos 70 é o texto de Jacques Revel e Jean-Pierre Peter (1986) intitulado "O corpo: o homem doente e sua história".

\section{REFERÊNCIAS}

ANÔNIMO.

Arte de furtar. Porto Alegre: L\&PM. 2005.

BENDA, Julien.

La trahison des clercs. Paris: Arthème Fayard. 1997.

BRAUDEL, Fernand.

A dinâmica do capitalismo. Rio de Janeiro: Rocco. 1989.

CERVANTES, Miguel de.

Dom Quixote de la Mancha. São Paulo: Abril Cultural. 1981.
DELUMEAU, Jean.

História do medo no Ocidente, 1300-1800. São Paulo: Companhia das Letras. 1996.

DUMAS, Alexandre.

Os três mosqueteiros. São Paulo: Abril Cultural. 1982.

ELIAS, Norbert.

O processo civilizador. Rio de Janeiro: Jorge Zahar. 1990.

FARQUHAR, Michael.

Escândalos reais. Rio de Janeiro: Ediouro. 2003. 
FEBVRE, Lucien.

O homem do século XVI. Revista de História, São Paulo, n.1, p.3-17. 1950.

HOLANDA, Sérgio Buarque de. Visão do paraíso. São Paulo: Brasiliense. 1994.

LACOUTURE, Jean.

Montaigne a cavalo. Rio de Janeiro: Record. 1998.

LADURIE, Emmanuel Le Roy.

O Estado monárquico: França 1460/1610.

São Paulo: Companhia das Letras. 1994.

LEFRANC, Abel.

A vida quotidiana no tempo do Renascimento. Lisboa: Livros do Brasil. 1938.

LEMONNIER, Léon.

A vida quotidiana em Inglaterra no tempo de Isabel I. Lisboa: Livros do Brasil. s.d.

MINOIS, Georges.

História do riso e do escárnio. São Paulo: Editora Unesp. 2003.

MONTAIGNE, Michel Eyquem de. Ensaios. São Paulo: Abril Cultural. 1972 .

MUCHEMBLED, Robert.

Société, cultures, mentalités dans la France moderne. Paris: Armand Colin. 1993.
REVEL, Jacques; PETER, Jean-Pierre.

O corpo: o homem doente e sua história. In: Le Goff, Jacques; Nora, Pierre (Org.). História: novos objetos. Rio de Janeiro: Francisco Alves. 1986.

RIBEIRO, Márcia Moisés.

A ciência nos trópicos: a arte médica no Brasil do século XVIII. São Paulo: Hucitec. 1997.

ROMANO, Ruggiero; TENENTI, Alberto. La estructura científica y técnica: la medicina. In: Romano, Ruggiero; Tenenti, Alberto. Los fundamentos del mundo moderno. Madrid: Siglo XXI. p.157-176. 1972.

SALLMANN, Jean-Michel.

As bruxas noivas de Satã. Rio de Janeiro: Objetiva. 2002.

STAROBINSKI, Jean.

Montaigne em movimento. São Paulo: Companhia das Letras. 1992.

TOURNON, André.

Montaigne. São Paulo: Discurso Editorial. 2003.

WATT, Ian.

Mitos do individualismo moderno. Rio de Janeiro: Jorge Zahar. 1997.

\section{$\rightarrow \rightarrow \rightarrow<<<$}

